\title{
Two new families (Acari: Alicorhagiidae and Platyhelminthes: Prorhynchidae) reported for the Hungarian fauna From leaf litter in the Bükk Mountains
}

\author{
W.P. PFLIEGLER ${ }^{1,2} \&$ S.J. BOLTON ${ }^{3}$ \\ ${ }^{1}$ Walter P. Pfliegler, Dept. of Biotechnology and Microbiology, University of Debrecen, $H 4032$ \\ Debrecen, Egyetem tér 1., Hungary.E-mail: walterpfliegler@gmail.com. ${ }^{2}$ Postdoctoral Fellowship \\ Program of the Hungarian Academy of Sciences (MTA), Hungary \\ ${ }^{3}$ Samuel J. Bolton, Department of Evolution, Ecology and Organismal Biology, The Ohio State \\ University, 1315 Kinnear Road, Columbus, Ohio, USA.E-mail: samuel.bolton77@gmail.com
}

\begin{abstract}
Two new members of the Hungarian fauna are reported, both of them were collected in beech forest leaf litter in the Bükk Mountains, North-East Hungary: Alicorhagia fragilis Berlese, 1910 (Arthropoda: Arachnida: Acari: Sarcoptiformes: Endeostigmata: Alicorhagiidae) and Geocentrophora baltica (Kennel, 1883) (Platyhelminthes: Rhabditophora: Trepaxonemata: Amplimatricata: 'Lecithoepitheliata': Prorhynchida: Prorhynchidae). The families Alicorhagiidae and Prorhynchidae both represent new taxa in the fauna of the country.
\end{abstract}

Keywords. Lecithoepitheliata, Endeostigmata, soil fauna, new record, Bükk National Park

\section{INTRODUCTION}

$\mathrm{T}$ The authors report on the finding of two interesting species of soil biota representing groups that are relatively under-studied in the Hungarian fauna. Both species represent new families for Hungary and were collected from beech leaf litter in the Bükk National Park, North-East Hungary, from the exact same location where a new species of mite for the Hungarian fauna (Pfliegler \& Bertrand 2011) and members of the Pauropoda with new faunistic records and a new species to science (Scheller et al. 2015) were found recently.

This particular area near the village Ómassa is located at the foot of a steep slope and the soil is covered with high stacks of beech (Fagus sylvatica) leaf litter (Fig. 1a.), while nearby areas have much shallower leaf litter coverage. The climate of the area is rather cool and it receives a very limited amount of sunlight year-round. The Garadna-spring is located some 10 meters downhill from the collection area, but it is very humid nevertheless, due to snowmelt and rainwater from the surrounding slopes flowing through it (personal observations).

Endeostigmata is among the most enigmatic groups of mites (along with the Sphaerolichina) and their distribution records are still very scarce. The taxon Endeostigmata includes mites with numerous primitive (plesiomorphic) characters and they are probably paraphyletic (Walter 2009). Within the Endeostigmata, the family Alicorhagiidae is characterized by a single pair of prodorsal trichobothria and absence of lateral claws on all of the pretarsi. Alicorhagia spp. are known to be thelytokous and they are omnivorous (Walter 2009). Within the family, this genus is characterized by the presence of five solenidia on tarsus I and also on tibia I in the adult stage. One family of the Endeostigmata, the vermiform Nematalycidae has been reported from Hungary so far, although this is an unpublished record (Norton et al. 2008). This mite was identified as Gordialycus tuzetae Coineau, Fize \& Delamare Deboutteville, 1967 from the Kiskunság National Park. These often extremely small and relatively species-poor soil mite groups are probably widespread across different habitats in the country. 
The Lecithoepitheliata is a relatively speciespoor group of flatworms split into the freshwater Prorhynchida and marine Gnosonesimida, but in fact the group is non-monophyletic according to recent molecular phylogenetic analyses (Laumer \& Giribet 2014, Laumer et al. 2015). Prorhynchidae is shown to be a sister group of the marine Polycladida (Laumer \& Giribet 2014, Egger et al. 2015, Laumer et al. 2015). Superficially they resemble minute freshwater Tricladida. The family Prorhynchidae is rather widespread in Europe (von Graff 1882, 1913). The species recorded in this work, Geocentrophora baltica (Kennel, 1883) can easily be distinguished from related flatworms (other members of Prorhynchidae), and generally, every other microscopic free-living flatworm by its hooked stylet opening into the mouth tube, which is visible even in low magnification (Fig. 3a-b.), lack of eyes, and tongue-shaped anterior (von Graff 1913; Steinböck 1927, Luther 1960). The species $G$. sphyrocephala de Man, 1876 has a very similar stylet but possesses eyes and has a very broad anterior (less characteristic in longer specimens). Relatively recently, Bauchness (1971) treated G. baltica as a synonym of $G$. sphyrocephala based on the subtle differences and overlapping characters, although this synonymyzation is not widely accepted. von Graff (1913) and Luther (1960) give the maximal length of G. baltica as 10-10.5 $\mathrm{mm}$ (fully extended). The species inhabits small forest waters formed after thaw, and puddles that form after flooding of meadows, and rarely soils and mosses (Bauchness 1971).

Research on the free-living flatworms ('Turbellaria' in traditional literature) of the Hungarian fauna dates back to the $19^{\text {th }}$ century and several species of every major freshwater group of these animals have been recorded from the country. However, the ever-changing systematics of Platyhelminthes, and the border changes of Hungary in the $20^{\text {th }}$ century makes evaluating older records problematic. The Fauna Regni Hungariae (Parádi 1896) lists a handful of species from locations mostly in Transylvania (now Romania), but none from the family Prorhynchidae. The family is also not listed in the earlier works of Parádi (1875,
1883). In the monograph of Rhabdocoelida, von Graff (1882) mentioned records of some flatworms from Hungary, but all of them are from the village Pancsova (now Pančevo in Serbia) and there is no mention of Prorhynchidae. In his extensive work in the series "Das Tierreich", von Graff (1913) mentioned the Hungarian distribution of the species Prorhynchus stagnalis Schultze M., 1851 without specific references. Publications from Hungarian authors did not mention the family Prorhynchidae, neither in the years between von Graff's works, nor later. Most articles focused on Tricladida (Fülep 2012 and references therein) and few discussed the members of lessknown taxa; Gelei (1930) almost entirely re-wrote the Turbellaria section of Brehm's Tierleben with an emphasis on the Hungarian fauna. Dudich (1942) and Andrássy (1984) shortly discussed all major flatworm taxa in Hungary - no mention of Prorhynchidae are given in these works. Thus the listing of the country in von Graff (1913) seems to be based on an unpublished and later forgotten record or may be an error. Steinböck (1927) gives a less accurate distribution of the species in the family (mostly as Europe), and he does not mention any Hungarian record. Luther (1960) mentions the record of $P$. stagnalis from Hungary and cites the Monographie der Turbellarien of von Graff, which is obviously an erroneous citation, as only von Graff's later work (in Das Tierreich) refers to the country. It can thus be concluded that the only relevant data of the family from Hungary was published by von Graff (1913) without specific information or reference, and it is impossible to determine whether von Graff's record comes from a location that is in present-day Hungary. Earlier literature therefore does not support the undoubtful occurrence of the family in the country.

\section{MATERIALS AND METHODS}

Samples of leaf litter were collected and stored in plastic containers for extended periods and regularly sprinkled with water. The samples were manually searched through and specimens were removed with a fine brush, photographed alive and conserved in $75 \%$ ethanol (both speci- 


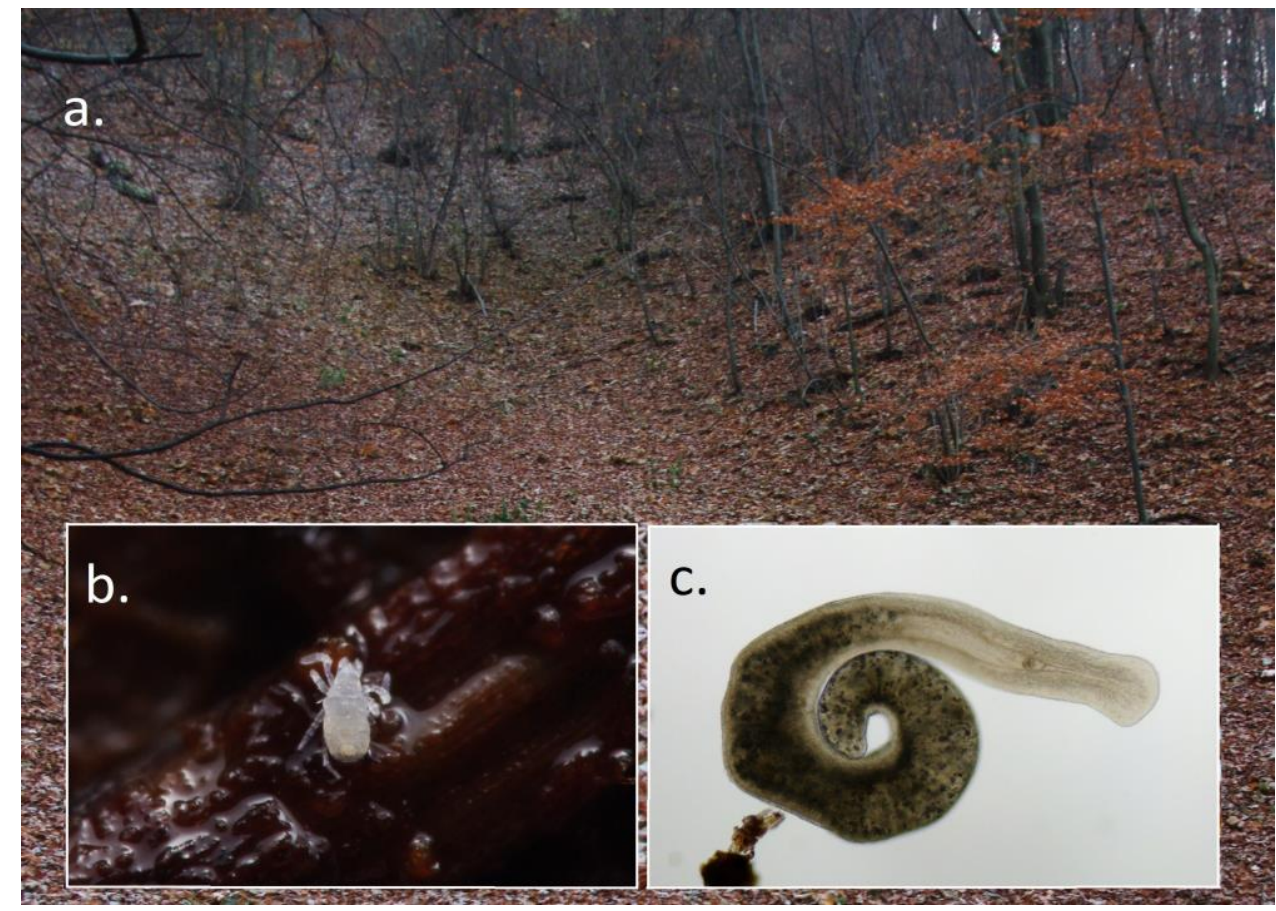

Figure 1. $\mathrm{a}=$ Collection locality near Ómassa, Bükk Mountains, N-E. Hungary. Date: 24.11.2011. $\mathrm{b}=$ habitus of Alicorhagia fragilis. $\mathrm{c}=$ habitus of Geocentrophora baltica .

es). In the case of Geocentrophora, one specimen was fixed in $4 \%$ formaldehyde, washed and mounted in glycerol, and sealed with euparal to allow photography with high magnification. Mites were subsequently washed and prepared onto slides in Heinz-PVA. Photographs were taken with a Pentax k7 DSRL camera, equipped with a macro lens setup and with the camera placed on a microscope equipped with a $10 \times$ Olympus Plan lens using transmitted light. Higher magnification photos were taken with an Olympus BD40 microscope equipped with Olympus $20 \times, 40 \times$ and $100 \times$ phase contrast lenses (Olympus Corporation, Tokyo, Japan) and an Olympus digital microscope camera with the software DP Controller (Olympus). Phase contrast microscopy images were focus-stacked using ZereneStacker (Zerene Systems LLC, Richland, WA, USA). Leg I of Alicorhagia fragilis was imaged using an Olympus Spectral FV1000 confocal laser scanning microscope. A 3D model of the leg was generated via a z-stack of the autofluorescence emission (laser $=488 \mathrm{~nm}$ ). An image of this model (Fig. 2b.) was created using Imaris (Bitplane, Zurich, Switzerland).

Images were enhanced in Photoshop CS6 (Adobe Systems Inc., San Jose, CA, US) and have been deposited in Morphbank (2015). Slidemounted specimens are deposited in the Zoology Collection of the Hungarian Natural History Museum (HNHM) and The Ohio State University Acarology Laboratory (OSAL). Taxonomy follows Walter et al. (2013) and Egger et al. (2015).

\section{RESULTS}

\section{Alicorhagiidae Grandjean, 1939 \\ Alicorhagia fragilis Berlese, 1910}

(Figures 1b, 2a-b)

Material examined. $2+$, Borsod-Abaúj-Zemplén county, Bükk Mountains, Ómassa village, $48^{\circ}$ $06^{\prime} 28.5^{\prime \prime} \mathrm{N} 20^{\circ} 31^{\prime} 51.4^{\prime \prime} \mathrm{E}$, beech forest, in leaf- 
litter, $500 \mathrm{~m}$ a.s.1., leaf litter sample collected on 24.11.2011, specimens collected on 02.01.2013 from the sample. Leg. W.P. Pfliegler.

Slide catalogue numbers. OSAL0099079 and OSAL0099080.

Accession numbers of photos in Morphbank. 856222 to 856225 (OSAL0099079) and 856226 to $856229,856232,856234,856235$ (OSAL 0099080).

Remarks. The specimens collected are in concordance with the characters of the widespread species A. fragilis. A. fragilis can be distinguished from the relatively similar $A$. usitata Theron, Meyer \& Ryke, 1971 based on the solenidia of the first leg. In A. usitata, the most distal solenidion on tibia I is clavate (Theron et al. 1969), whereas in A. fragilis this solenidion is relatively baculiform (Fig. 2b.). Another important distinguishing feature is the positions of the three long, thin solenidia on tarsus I. In A. usitata, one of these solenidia is near the long, broad solenidion (Theron et al. 1969), whereas in A. fragilis all three of these solenidia have distinctly proximal positions relative to the long, broad solenidion (Fig. 2b.).

The original description of $A$. fragilis provides inadequate information for a confident and robust identification (Berlese 1910). Unfortunately, the holotype is in poor condition. However, topotypes from the same botanical garden have been collected and deposited at the Museum of Biological Diversity, Ohio State University (OSAL nos. 0104484, 0104485, 0104486). These appear to be identical to the two Hungarian specimens, which are both adult females. These specimens also very closely resemble the Japanese specimen of $A$. fragilis that was drawn by Shiba (1983).

\section{Prorhynchidae Hallez, 1894}

\section{Geocentrophora baltica (Kennel, 1883)}

(Figures 1b, 3-b)

Material exmined. 1 specimen, Borsod-AbaújZemplén county, Bükk Mountains, Ómassa village, $48^{\circ} 06^{\prime} 28.5^{\prime \prime} \mathrm{N} 20^{\circ} 31^{\prime} 51.4^{\prime \prime} \mathrm{E}$, beech forest, in leaf-litter, $\sim 500 \mathrm{~m}$ a.s.l., leaf litter sample collected on 24.11.2011, specimens collected on 05.02. 2012 from the sample. Leg. W.P. Pfliegler. Slidepreparate.

Accession numbers of photos in Morphbank. (856230, 856231).

Slide catalogue number. HNHM Gyn. 878.

Remarks. A high definition video of the specimen collected on 05.02.2012 is available at the following URL:

https://www.youtube.com/watch?v=ytmsmEgeHTg showing the animal moving under a coverslip with transmitted light.

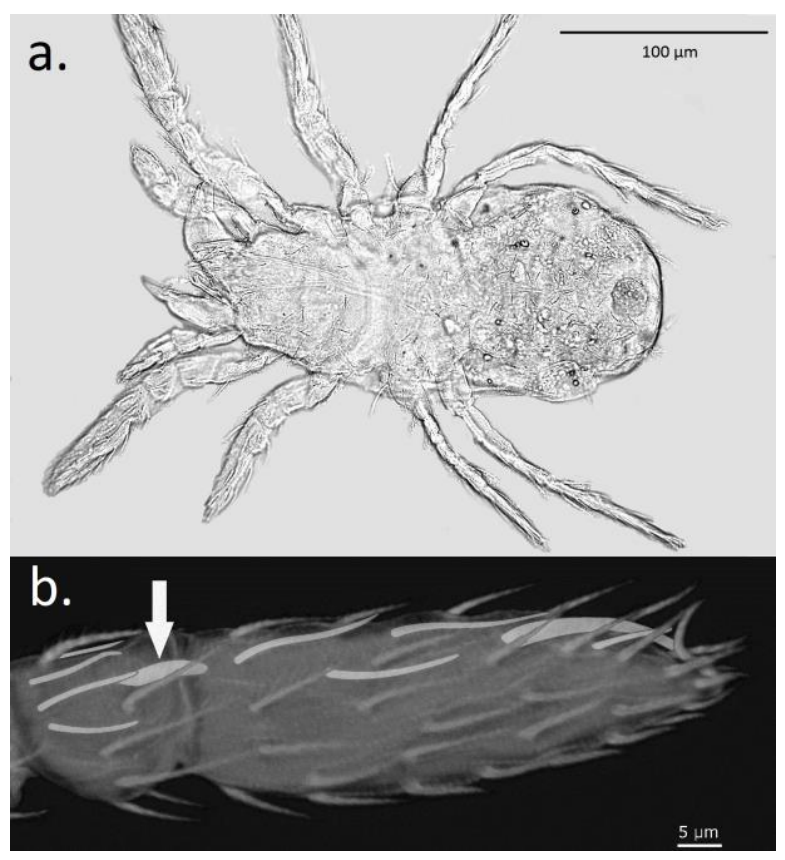

Figure 2. Microscopic anatomy of Alicorhagia fragilis (specimen OSAL0099080). a = mounted specimen, ventral view (phase contrast image). $\mathrm{b}=$ View of tibia I and tarsus I (same specimen). This is an image of a 3D model generated using a confocal laser scanning microscope. The solenidia have been artificially highlighted because of their weak autofluorescence. The arrow points to the relatively baculiform solenidion (which is distinctly clavate in A. usitata).

\section{DISCUSSION}

Both species reported in this work (and also the families they are classified in, Alicorhagiidae and Prorhynchidae) are widespread but under- 
studied, minute animals inhabiting soil and leaf litter, and in the case of Geocentrophora, mostly small water bodies. Both of the species belong in species-poor families that would nevertheless greatly benefit from a taxonomic revision; $G$. baltica is sometimes considered a synonym of $G$. sphyrocephala (e. g. Luther 1960, Bauchness 1971) based on the fact that the presence or absence of eyes in these flatworms is, as well as the body shape, variable (loss of eyes may occur gradually during their ontogeny), while the shape of the stylet does not adequately distinguish the two species. In contrast to this, the recent multigene phylogenetic analysis of Laumer \& Giribet (2014) placed these species on two different clades of the family Prorhynchidae. G. baltica and G. sphyrocephala are often found sympatrically (Bauchness 1971). Both Geocentrophora species are cosmopolitan and typically found in periodically flooded or muddy areas and on the banks of watercourses (Timoshkin 1991, Young 2001).

G. baltica is the second terrestrial flatworm recorded from Hungary - the other being the triclad (Tricladida: Geoplanidae) Microplana terrestris (Müller O.F., 1773) known from Budapest (Parádi 1896). The mite Alicorhagia fragilis represents the second known species of the Endeostigmata in Hungary.

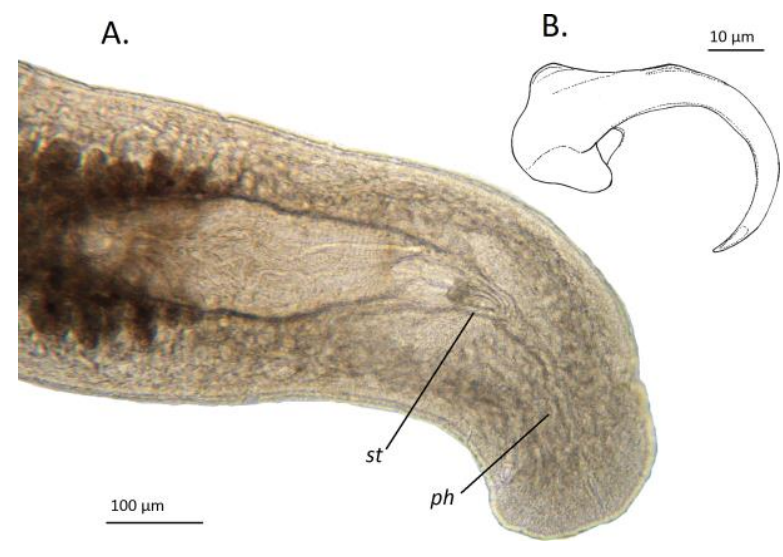

Figure 3. Microscopic anatomy of Geocentrophora baltica. $\mathrm{A}=$ alive specimen, anterior part. $\mathrm{B}=$ stylet of the mounted specimen (drawing). ph: pharynx. st: stylet.
Acknowledgements - The authors are indebted to Dr. Bernhard Egger (Innsbruck University) for his comments on Geocentrophora and the manuscript.

\section{REFERENCES}

ANDRÁSSY, I. (1984): Laposférgek állattörzse - Platyhelminthes. In. MócZÁR, L. (Ed.) Állathatározó 1. Tankönyvkiadó, Budapest, p. 36-39.

BAUCHNESS, J. (1971): Die Kleinturbellarien Frankens. Ein Beitrag zur Systematik und Ökologie der Turbellaria excl. Tricladida in Süddeutschland. Internationale Revue der gesamten Hydrobiologie und Hydrographie, 56(4): 609-666. doi: 10.1002/iroh.19710560407

BerLese, A. (1910): Lista di nuovi generi di Acari. Redia, 6: 242-271

Dudich, E. (1942): Az állatok rendszere. In: SoÓs, L. \& Dudich, E. (Eds.) Az állat és élete II. Királyi Magyar Természettudományi Társulat, Budapest, $335 \mathrm{pp}$.

EgGer, B., Lapraz, F., TomiczeK, B., Müller, S., Dessimoz, C., Girstmair, J., ŠKunCa, N., RaWLinson, K.A., CAMERON, C.B., Beli, E., TOdARO, M.A., Gammoudi, M., NoreÑA, C. \& Telford, M.J. (2015): A transcriptomic-phylogenomic analysis of the evolutionary relationships of flatworms. Current Biology, 25(10): 1347-1353. doi: 10.1016/j.cub.2015.03.034

FÜLEP, T. (2012): Az édesvízi planáriák (Platyhelminthes: „Turbellaria”: Tricladida) magyarországi bibliográfiája és kutatástörténete. Acta Biologica Debrecina Supplementum Oecologica Hungarica, 28: 91-108.

GeleI, J. (1930): 1. osztály: Örvényférgek (Turbellaria). (Magyar átültetés Hempelmann, F. \& Wagler, E.: A férgek (Vermes) állattörzse cimü fejezetében.). In. GELEI, J. (Ed.) Brehm: Az állatok világa 18. Alsórendủ állatok 2 . Férgek, tömlősök, szivacsok, véglények és a sejtekre tagoltak, sejtekre nem tagoltak általában. Gutenberg Könyvkiadó vállalat, Budapest, p. 109-137.

VON GRAFF, L. (1882): Monographie der Turbellarien. I. Rhabdocoelida. Verlag von Wilhelm Engelmann, Leipzig. 445 pp.

VON GRAFF, L. (1913): Platyhelminthes. Turbellaria. II. Rhabdocoelida. Das Tierreich 35. Deutsche zoologische Gesellschaft. Berlin, Verlag von R. Friedländer und Sohn, 484 pp. 
LAUMER C.E. \& GIRIBET, G. (2014): Inclusive taxon sampling suggests a single, stepwise origin of ectolecithality in Platyhelminthes. Biological Journal of the Linnean Society, 111: 570-588. doi: $\underline{10.1111 / b i j .12236}$

Laumer, C.E., HejnOl, A., GIRIBET, G. (2015): Nuclear genomic signals of the 'microturbellarian' roots of platyhelminth evolutionary innovation. eLife, 4: e05503. doi: $10.7554 /$ LLife. 05503

LUTHER, A. (1960): Die Turbellarien Ostfennoskandiens I. Acoela, Catenulida, Macrostomida, Lecithoepiteliata, Prolecithophora, und Proseriata. Fauna Fennica 7. Societas pro Fauna et Flora Fennica, Helsinki - Helsingfors, 154 pp.

MORHBANK (2015): Biological Imaging (http://www. morphbank.net/ 15 October 2015). Florida State University, Department of Scientific Computing, Tallahassee, FL 32306-4026 USA.

Norton, R.A., Oliveira A.L. \& De Morales G.J. (2008): First Brazilian records of the acariform mite genera Adelphacarus and Gordialycus (Acari: Acariformes: Adelphacaridae and Nematalycidae). International Journal of Acarology, 34(1): 91-94. doi: 10.1080/01647950808683709

PARÁDI, K. (1875): Két jelenség az örvény férgek életéből. Erdélyi Múzeum, 2(9): 137-142.

PARÁDI, K. (1883): Jelentés az erdélyi vizek örvényférgeire tett kutatások eredményéröl. Mathematikai és Természettudományi Közlemények, 18: 98-116.

PARÁDI, K. (1896): Subphylum Platyhelminthes. Classis Turbellaria. In. PASZlavszKY, J. (Ed.) A Magyar Birodalom Állatvilága. A magyar birodalomból eddig ismert állatok rendszeres lajstroma. (Fauna Regni Hungariae). Magyar Királyi Természettudományi Társulat, Budapest, 2 pp.

Pfliegler, W. \& Bertrand, M. (2011): A new species of Labidostomma Kramer, 1879 for the fauna of Hungary (Acari: Trombidiformes: Labidostommatidae) with an overview of the family. Opuscula Zoologica Budapest, 42: 177-183.

Scheller, U., Pfliegler, W.P. \& Korsós, Z. (2015): Pauropoda (Myriapoda) records from Hungary with description of a new species. Acta Zoologica Academiae Scientiarum Hungaricae, 61(2): 81-86. doi: 10.17109/AZH.61.2.81.2015

SHIBA, M. (1983): Three species of the genus Alicorhagia Berlese (Acarina: Actinedida) from Japan. Reports of research Matsuyama Shinonome Junior College, 14: 81-89.

STEINBÖCK, O. (1927): Monographie der Prorhynchidae (Turbellaria). Zeitschrift für Morphologie und Ökologie der Tiere, 8(3-4): 538-662. doi: $\underline{10.1007 / \mathrm{BF} 00407451}$

Theron, P.D., MEYER, M.K.P. \& RYKE, P.A.J. (1970): The family Alicorhagiidae Grandjean (Acari: Trombidiformes) with descriptions of a new genus and species from South African soils. Acarologia, 12: $668-676$.

TIMOSHKIN, O.A. (1991): Turbellaria, Lecithoepitheliata: morphology, systematics, phylogeny. Hydrobiologia, 227(1): 323-332. doi: 10.1007/BF00027618

WALTER, D.E. (2009): Suborder Endeostigmata. In. Krantz, G.W. \& WALTER, D.E. (Eds.) A Manual of Acarology, Third Edition. Texas Tech University Press, p. 421-429.

Walter, D.E., Bolton, S., Uusitalo, M., \& Zhang, Z.-Q. (2013): Suborder Endeostigmata Reuter, 1909. In. ZHANG, Z.-Q. (Ed.) Animal biodiversity: An outline of higher-level classification and survey of taxonomic richness. Zootaxa, 3148: 139-140.

YounG, J.O. (2001): Keys of the Freshwater Microturbellarians of Britain and Ireland with notes on their Ecology. Freshwater Biological Association Scientific Publication 59, Ambleside, 142 pp. 